\title{
Social-Demographic Losses Inflicted By Infant Death-Rate in Republic of Ingushetiya
}

\author{
Artur A. Almukhametov ${ }^{1}$, Anas A. Gilmanov², Aleksandr I. Glushakov ${ }^{3}$, Magomedbashir H. Balaev $^{4}$, \\ Ildar R. Iskandarov ${ }^{5}$ \\ ${ }^{1}$ Kazan Federal University, Medical Sanitary; Kazan State Medical University, Ministry of Health of the Russian \\ Federation, 2, 3, 4, 5 Kazan State Medical University, Ministry of Health of the Russian Federation \\ Email: artyr_efendi@mail.ru, Contact: 89179018704
}

Received: 21st October 2017 Accepted: 16th November 2017, Published: 31st December 2017

\begin{abstract}
The paper is devoted to assessment of changes of the main social and demographic parameters and calculation of economic losses under the influence of infant death rate. For this purpose we have built two tables to obtain death rate for Republic Ingushetia based on materials for 2014. First table is formed under existing level of death rate; the second table presents the level for infants with the age of up to full 1 year of life. Results and discussion have shown that the death of infants leads to reducing a remaining life expectancy of newborns (about 1.21-1.42 for boys and 0.76-1.48 for girls); duration of the able-bodied period (by 0.66 0.77 for males and $0.35-0.69$ for females) and the forthcoming labor activity (about 1.6-1.9\% for males and $0.9-1.8 \%$ for females); results for reproduction of the population (by $0,7-1,8 \%$ ); and amount of a social production for $1.47 \%$. Conclusion was that approximate "cost" of one death till 1st year of life taking into account the half-received public product has amounted 6.532 million rubles.
\end{abstract}

Keywords: Infant Death Rate, Life Expectancy, Net Factor, Reproducing the Population, Health.

\section{Introduction}

The death of a child at the very beginning of his or her life path, which is the death in the period of infancy, is not only a humanitarian loss for his or her parents and society, but also the loss of a his or her entire life and its labor part, during which the future citizen could take part in the creation of wealth for his or her country.

The purpose of this study is to assess changes in the main socio-demographic parameters and calculate economic losses due to infant mortality.

\section{Methods}

We built two mortality tables for the necessary calculations, using the method of Chiang CL (1968) and Medkov V.M. (2002) for the Republic of Ingushetia (RI) based on official statistical materials for 2014. The first table was compiled with the actual level of age-related mortality; the second is in case of complete survival or elimination of death at the first year of life.

It is possible to determine the extent of the mortality impact on the change in individual socio-demographic parameters according to the following indicators [6]: the life expectancy of a newborn; length of able-bodied period, commitment in public production; and net reproduction rate of the population.

The gain in the life expectancy of a newborn as a result of the reduction in the infant mortality rate is interpreted according to the accepted methodological approaches [3].

The assessment of the possible increase in the length of able-bodied period and commitment in the public production is carried out according to the following stages [2]:

(a) Determination of the deferred temporary life expectancy of a newborn at working ages $(n) t E_{0}$, which is a "rough" estimate of the reduction in the period of work capacity as a result of infant mortality:

$$
(\mathrm{n}) \mathrm{tE}_{0}=\left(\mathrm{T}_{\mathrm{n}}-\mathrm{T}_{\mathrm{t}}\right) / \mathrm{I}_{0}
$$

where $\mathrm{T}_{\mathrm{n}}$ and $\mathrm{T}_{\text {tare }}$ the life potentials of persons who survive to the beginning of labor period (15 years) and its end ( 55 years for females and 60 years for males); $\mathrm{I}_{0}$ - number of newborns according to mortality tables;

b) Definition of the deferred working expectancy $\left(E_{\operatorname{Tr} 0}\right)$ taking into account the age levels of labor activity of the population [2]:

$$
\mathrm{E}_{\mathrm{Tp} 0}=\left(\sum \mathrm{L}_{\mathrm{x}} \times \mathrm{g}_{\mathrm{x}}\right) / \mathrm{I}_{0}
$$

for which the level of employment in the social production process is determined $\left(\mathrm{g}_{\mathrm{x}}\right)$ as:

$$
g_{x}=S_{x} / S_{x}
$$

Where $S_{x}$ - the age and sex composition of the population engaged in social production;

$S_{x}$ - the age and sex composition of the population in general;

c) Determination of the expected increase in the volume of forthcoming labor activity $\left(\Delta T_{T p}\right)$ is conducted through an assessment of the change in the magnitude of the life potential during the period of labor activity or labor potential $\left(\Delta T_{T p}\right)_{\text {[2]: }}$

$$
\mathrm{T}_{\mathrm{Tp}}=(1-\mathrm{d}) \times \sum \mathrm{L}_{x}^{m} \times \mathrm{g}_{\mathrm{x}}^{\mathrm{m}}+\mathrm{d} \times \sum \mathrm{L}_{\mathrm{x}}^{\mathrm{f}} \times \mathrm{g}_{\mathrm{x}}^{\mathrm{f}}
$$

where $d$ is the proportion of girls in the number of children born; 
$L_{x}^{m}$ and $\mathrm{L}_{\mathrm{x}}^{\mathrm{f}}$ - number of males (m) and females (f) living individuals in the static population at the age of $\mathrm{x}$ according to the mortality tables;

$\mathrm{g}_{\mathrm{x}}^{\mathrm{m}}$ and $\mathrm{g}_{\mathrm{x}}^{\mathrm{f}}$ - the proportion of persons aged $\mathrm{x}$ years of the males (m) and females (f) in the stationary population employed in social production, according to the mortality tables.

$$
\Delta \mathrm{T}_{\mathrm{Tp}}=\left(\mathrm{T}_{\mathrm{Tp}}^{\mathrm{i}}-\mathrm{T}_{\mathrm{Tp}}\right) / \mathrm{T}_{\mathrm{Tp}}
$$

Where $\Delta \mathrm{T}_{\mathrm{Tp}}$ - the share of growth in the volume of forthcoming labor activity;

$\mathrm{T}_{\mathrm{Tp}}^{\mathrm{i}}$ - the life potential provided that the mortality (or elimination) decreases.

The increase in the return on the implementation of the reproductive functions of a larger number of girls surviving to fertile ages (15-49 years) is determined using the methodology for calculating the net reproduction rate of the population (net-RRP):

$$
R_{0}=\left[\left(\sum L_{x}^{f} \times A S F R\right) \times d\right] / I_{0}
$$

Where ASFR are the age-related fertility rates.

Assessment of Economic Damage caused by mortality is calculated by multiplying the proportion of the expected growth in the volume of forthcoming labor activity $\left(\Delta T_{T p}\right)$ on the gross domestic product (GDP, in the Republic of Ingushetia - in billion rubles) produced within one year [2]:

$$
\Delta \mathrm{GDP}=\mathrm{GDP} \times \Delta \mathrm{T}_{\mathrm{Tp}}
$$

Table 1: The Actual and Hypothetical Life Expectancy of a Newborn among Males and Females in Urban and Rural Areas (as of the Republic of Ingushetia for 2014), years

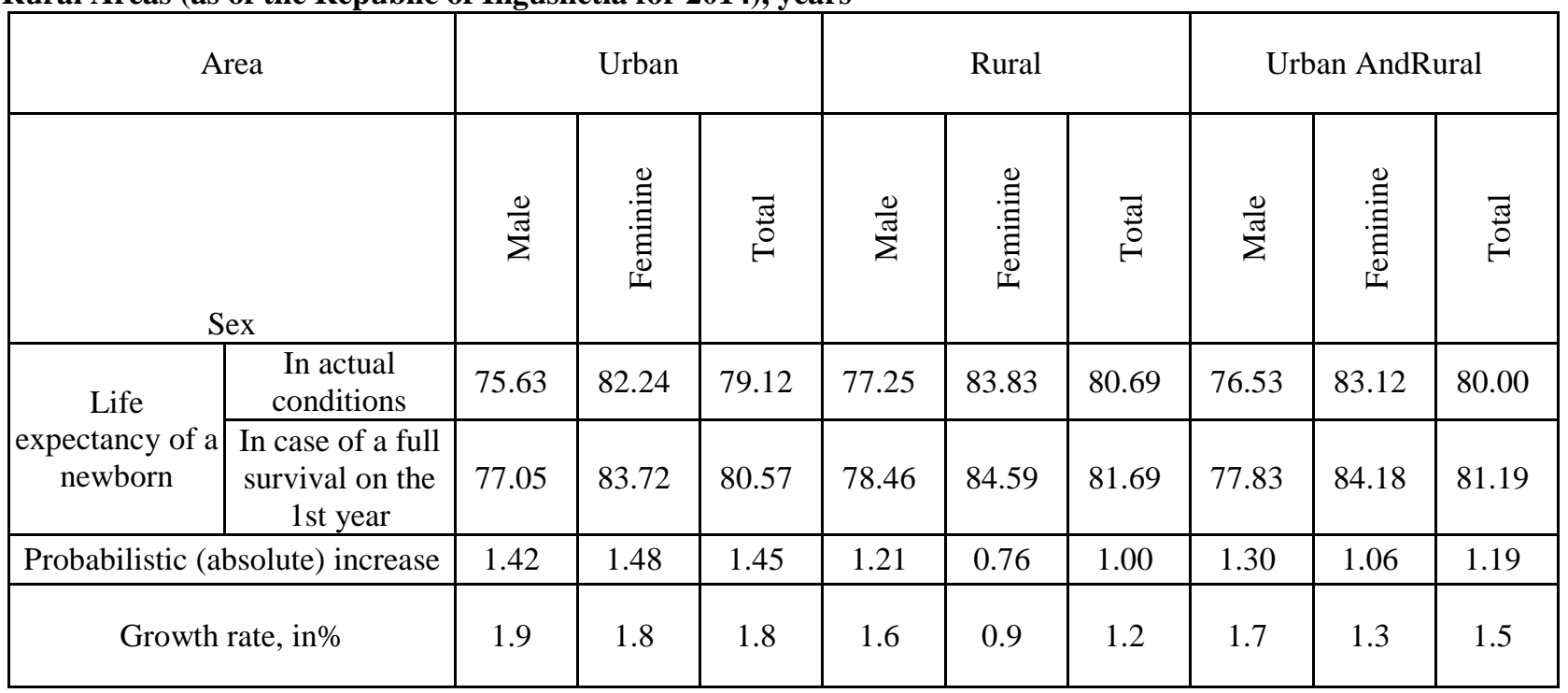

Source: Calculated on the basis of the data represented by the Territorial Body of the Federal State Statistics Service (FSSS) for the Republic of Ingushetia.

To determine the deferred temporary life expectancy of a newborn in the working period, we find the vital potential value according to the mortality table in actual and hypothetical conditions for the beginning ( $\mathrm{T}$
It is possible to determine the economic effect from preserving the life of the child with the help of an indicative estimated value of the lost surplus product as a result of one death [4]. Taking into account males and females life expectancy and work activity, the formula will look like this:

$$
\ni=(1-d) \times\left(n x \frac{B B \Pi}{P} \times E_{T p}^{m_{0}^{i}}-\frac{\Phi}{\mathrm{H}} \times\left(e^{m} 0^{i}-E_{T p}^{m^{m}}{ }^{i}\right)\right)+c
$$

Where we added to already known values:

$\mathrm{n}$-a coefficient that takes into account the ratio of the surplus product value to the whole newly created value (0.5),

P-number of people employed in the national economy;

$\mathrm{F}$ - public consumption funds, billion rubles;

$\mathrm{H}$ - total population, people.

\section{Results and Discussion}

Infant mortality can reduce the life expectancy of a newborn in urban and rural areas in the Republic of Ingushetia by 1.21-1.42 years (or 1.6-1.9\%) among males and by $0.76-1.48$ years (or $0.9-1.8 \%$ ) among females (Table.1).

If the gain that results in the elimination of death at the first year of life seems small (0.76-1.48 years), the best commentary is the words of the medical demographer Professor Bedny M.S: "... when the life expectancy is high, even an increase of $1 / 2$ or $1 / 3$ of a year may indicate the most important trends occurring in mortality"[1]. n) and for the end $\left(\mathrm{T}_{t}\right)$ of labor activity, and then substituting them, we get the deferred temporary life expectancy in the able-bodied period (n) $\mathrm{tE}_{0}$ for boys born in urban areas in the Republic of Ingushetia: 
- for the actual mortality table:

(n) $t E^{m}$ ocity $=(6095609-1939582)$ persone - years $/ 100000$ persone $=41,56$ years

- for the hypothetical mortality table:

$(n) t E_{0^{i} \text { city }}^{m}=(6209206-1975728)$ persone- years $/ 100000$ persone $=42,33$ years

For girls born in urban areas in the Republic of Ingushetia: $(n) t E^{\mathrm{f}}{ }_{0 \text { city }}=(6756740-2887140)$ persone- years $/ 100000$ persone $=38,70$ years etc.

Calculating (n) $\mathrm{tE}_{0}$ for the actual and hypothetical mortality tables, we obtain a probabilistic increase in the deferred temporary life expectancy of a newborn in the working period (Tab.2).

Table 2: Actual and Hypothetical Deferred Temporary Life Expectancy of a Newborn in Working Age among Males and Females in Urban and Rural Areas (As of the Republic of Ingushetia for 2014), Years

\begin{tabular}{|c|c|c|c|c|c|c|c|c|c|c|}
\hline \multicolumn{2}{|l|}{ Area } & \multicolumn{3}{|l|}{ Urban } & \multicolumn{3}{|l|}{ Rural } & \multicolumn{3}{|c|}{ Urban and Rural } \\
\hline \multicolumn{2}{|l|}{ Sex } & $\frac{0}{\sum^{\pi}}$ & : & 丞 & $\frac{0}{\sum}$ & 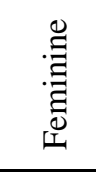 & تే & $\frac{0}{\sum^{\pi}}$ & 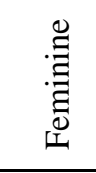 & 营 \\
\hline \multirow{2}{*}{$\begin{array}{l}\text { Deferred } \\
\text { temporary life } \\
\text { expectancy of a } \\
\text { newborn in the } \\
\text { working period }\end{array}$} & $\begin{array}{ll}\text { In } & \text { actual } \\
\text { conditions }\end{array}$ & 41.56 & 38.70 & 40.18 & 42.21 & 39.09 & 40.65 & 41.92 & 38.93 & 40.43 \\
\hline & $\mid \begin{array}{l}\text { In case of a full } \\
\text { survival on the } 1 \mathrm{st} \\
\text { year }\end{array}$ & 42.33 & 39.39 & 40.86 & 42.87 & 39.44 & 41.15 & 42.63 & 39.43 & 41.03 \\
\hline \multicolumn{2}{|c|}{ Probabilistic (absolute) increase } & 0.77 & 0.69 & 0.68 & 0.66 & 0.35 & 0.50 & 0.71 & 0.50 & 0.60 \\
\hline \multicolumn{2}{|l|}{ Growth rate, in $\%$} & 1.9 & 1.8 & 1.7 & 1.6 & 0.9 & 1.2 & 1.7 & 1.3 & 1.5 \\
\hline
\end{tabular}

Source : Calculated on the basis of the data represented by the Territorial Body of the Federal State Statistics Service for the Republic of Ingushetia.

Note: * - for males of 16-59 years (duration - 44 full years), for females of 16-54 years (duration - 39 full years).

Death in the infant period can lead to a further decrease in working-age living in urban and rural areas in the Republic of Ingushetia by $0.66-0.77$ years (or 1.6$1.9 \%$ ) for males and $0.35-0,69$ years (or $0.9-1.8 \%$ ) for females.

This indicator is supplemented by taking into account the real participation in public production, the deferred temporary working expectancy (DTWE), for this purpose the levels of age-related employment of the population in the national economy $\left(\mathrm{g}_{\mathrm{x}}\right.$ and $\mathrm{g}{ }_{\mathrm{x}}^{\mathrm{f}}$ ), which remain unchanged throughout life.
Thus, every newborn boy in urban areas in the Republic of Ingushetia will have to live in the period of labor activity (15-69 years):

- in real conditions:

$E^{\mathrm{f}}{ }_{0 \text { city }}=(6756740-2887140)$ persone - years $/ 100000$ persone $=38,70$ years

$E_{T p}{ }^{m}$ 0ity $=3011581$ persone - years $/ 100000$ persone $=30,11$ years

- in the absence of infant mortality:

$E_{T p}{ }^{m}{ }^{i}{ }^{i}$ city $=3067784$ persone - years 100000 persone $=30,68$ years

And further, for males and females in urban areas, as well as in rural areas and in general for urban and rural areas (see Tab. 3). 
Table 3: Actual and Hypothetical Deferred Temporary Working Expectancy among Males and Females in Urban and Rural Areas (As of the Republic of Ingushetia for 2014), Years

\begin{tabular}{|c|c|c|c|c|c|c|c|c|c|c|}
\hline \multicolumn{2}{|c|}{ Area } & \multicolumn{3}{|c|}{ Urban } & \multicolumn{3}{|c|}{ Rural } & \multicolumn{3}{|c|}{ Urban and Rural } \\
\hline \multicolumn{2}{|c|}{ Sex } & $\frac{0}{\sum^{J}}$ & .气 & 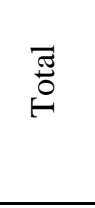 & $\frac{0}{\Sigma}$ & . & 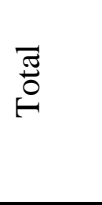 & $\frac{\frac{0}{J}}{\Sigma}$ & 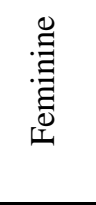 & $\stackrel{\pi}{0}$ \\
\hline \multirow{2}{*}{$\begin{array}{l}\text { Deferred } \\
\text { temporary } \\
\text { expected } \\
\text { duration of } \\
\text { employment } \\
\end{array}$} & $\begin{array}{l}\text { In actual } \\
\text { conditions } \\
\end{array}$ & 30.11 & 27.58 & 28.77 & 24.40 & 21.38 & 22.95 & 28.73 & 26.14 & 27.39 \\
\hline & $\begin{array}{l}\text { In case of a full } \\
\text { survival on the } \\
1 \text { st year }\end{array}$ & 30.68 & 28.07 & 29.30 & 24.78 & 21.57 & 23.23 & 29.21 & 26.47 & 27.79 \\
\hline \multicolumn{2}{|c|}{ Probabilistic (absolute) increase } & 0.57 & 0.49 & 0.53 & 0.38 & 0.19 & 0.28 & 0.48 & 0.33 & 0.40 \\
\hline \multicolumn{2}{|c|}{ Growth rate, in $\%$} & 1.9 & 1.8 & 1.8 & 1.6 & 0.9 & 1.2 & 1.7 & 1.3 & 1.5 \\
\hline
\end{tabular}

Source: Calculated on the basis of the data represented by the Territorial Body of the Federal State Statistics Service for the Republic of Ingushetia.

Attention should be drawn to the fact that the total duration of all labor activity in rural and urban areas in the Republic of Ingushetia (24.78-30.68 years for males and 21.57-28.07 years for females) which even goes beyond the active working age is much less than rated duration of stay (42.87-42.33 years and 39.4439.39 , respectively) in this period due to incomplete involvement in the production process of the population (students, disabled, unemployed, etc.)).

Implementation of Reproductive Functions: The possible increase in the number of girls surviving to fertile or childbearing age, contributes to the increase in the number of children they can give birth. Therefore, the "cumulative" number of females of childbearing period (15-49 years) with the time of their life and the level of fertility is a "fertility potential" [3].
Taking into account the fact that the share of born girls among all children of the Republic of Ingushetia for 2014 was 0.506 , then transferring these proportions to the "expected" number of children born to 100 thousand females in urban areas of the Republic of Ingushetia, we obtain a net reproduction rate of the population ( $\left.\mathrm{R}_{0 \text { city }}\right)$ :

- For the actual mortality table:

$R_{0 \text { city }}=201396$ women $\times 0.506$ irls $/ 100000$ womens $=1.019 \mathrm{girls}$

- For the hypothetical mortality table:

$R_{0^{i} \text { city }}=204999$ womens $\times 0.506$ irls $/ 100000$ womens $=1.037$ girls

So, at zero death level at the 1 st year of life at the current fertility levels among females of 15-49 years, there would be an increase in the net reproduction rate of the population in rural and urban areas in the Republic of Ingushetia by $0.7-1.8 \%$ (see Table . 4).

Table 4: The Actual and Hypothetical Net Reproduction Rate of the Population in Urban and Rural Areas (As of the Republic of Ingushetia for 2014), The Number of Girls Born by One Woman aged of 15-49

\begin{tabular}{|l|l|c|c|c|}
\hline \multicolumn{2}{|l|}{ Area } & Urban & Rural & Urban and Rural \\
\hline $\begin{array}{l}\text { Net reproduction } \\
\text { ratio }\end{array}$ & In actual conditions & 1.019 & 1.368 & 1.218 \\
\cline { 2 - 5 } & $\begin{array}{l}\text { In case of complete survival at the 1st } \\
\text { year }\end{array}$ & 1.037 & 1.377 & 1.233 \\
\hline Probabilistic (absolute) increase & 0.018 & 0.009 & 0.015 \\
\hline Growth rate, in\% & 1.8 & 0.7 & 1.2 \\
\hline
\end{tabular}

Source: Calculated on the basis of the data represented by the Territorial Body of the Federal State Statistics Service for the Republic of Ingushetia.

The Expected Increase in the Volume of the Forthcoming Labor Activity of a conditional generation or an increase in the labor potential $\left(\Delta \mathrm{T}_{\mathrm{Tr}}\right)$ is possible if the mortality caused by the group of causes is completely excluded (or decreased). 2395
The total potential ability to work of the population now and in the future can be interpreted as labor potential, which is a more "voluminous concept than labor resources, since it is characterized not only by the number of separate age groups, but also by the time of 
their life, during which a certain set of the whole or able-bodied population can take part in the social labor process "[6].

Specifically, in our calculations for urban and rural areas of the Republic of Ingushetia, it will be:

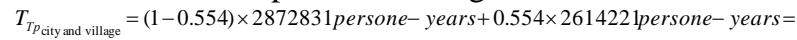
$=2729561$ persone - years

and

$T_{T p}^{i}$ city and village $=(1-0.554) \times 2921399$ persone - years $+0.554 \times 2647497$ persone - years $=$ $=2769657$ persone - years

$\Delta T_{T_{P \text { city and village }}}=(2769657-2729561)$ persone - years $/ 2729561$ persone - years $=0.014$
- Duration of stay in the working age (by 0.66-0.77 years for males and 0.35-0.69 years for females) and the duration of future work (by 1.6-1.9\% for males and $0.9-1.8 \%$ for females);

- Results of population reproduction (by $0.7-1.8 \%$ );

- The volume of social production by $1.47 \%$ (or 586.5 million rubles).

The estimated "cost" of one death before the first year of life, taking into account the social product in the Republic of Ingushetia which has not been received and prices in 2014 amounted to 6.532 million rubles.

\section{Acknowledgments}

The work is carried out according to the Russian Government Program of Competitive Growth of Kazan Federal University.

leading criteria which determine the final results of activity at any level of economical activity, are the indicators of economic efficiency [4].The effect is possible with a decrease in economic losses or losses from diseases, disability, and premature mortality.

To determine the total economic damage caused by infant mortality, we multiply the proportion of the expected increase in the volume of future work activity $\Delta \mathrm{T}_{\mathrm{Tp}}$ by the value of gross domestic product (GDP) produced during one year of labor activity [2].

The volume of GDP in the Republic of Ingushetia for 2014 amounted to 39.9 billion rubles; we substitute it into the formula:

$$
\Delta \mathrm{GDP}=39,9 \times 10^{9} r u b \times 0.0151 \approx 0.5865 \times 10^{9}
$$

\section{References}

1. Bedny M.S. Medico-demographic study of population. - M., 1979. - 223 p.

2. Borokhov D.Z. Influence of mortality on the average duration of the forthcoming labor activity // Bulletin of Statistics. - 1975. - No. 1. - P. 30-34.

3. Korchak-Chepurkovsky Yu.A. Influence of mortality in different ages on an increase in the average life expectancy / Soviet demography over 70 years. M., 1987. - P. 263-280.

4. Kulagina E.N. Economic efficiency of health prbtection. - Gorky, 1984. - 159 p.

5. $\quad$ Petrov P.P., Borokhov D.Z., Kulzhanov M.K., Kashafutdinova G.T. Medico-demographic and sociohygienic aspects of infant mortality and its contributing factors // Soviet public health. - 1991. - No. 3. - P. 3437.

6. Lang T.A., Sesik M. How to describe the statistics in medicine: a guide for authors, editors and reviewers. MM: Scient. Medicine, 2011. 477. (in Russian).

7. Campbell M.J. Medical statistics: a textbook for the health sciences. / M.J. Campbell, D. Machin, S.J. Walters. - 4th ed. / John Wiley \& Sons, Ltd., 2007. $-331 \mathrm{p}$.

8. Matthews D.E. Using and understanding medical statistics / D.E. Matthews, T.V. Farewell. 4th, completely rev. and enl. ed./ S. Karger AG, 2007. $-322 \mathrm{p}$.

9. Peacock J.L. Oxford Handbook of Medical Statistics /J.L. Peacock, P.J. Peacock / Oxford University Press, 2011. - 517 p.

10. Petrie A. Medical statistics at a glance / A. Petrie, C. Sabin. - 3rd ed./ Wiley Blackwell, 2009. $181 \mathrm{p}$. $\ni=\left[(1-0,554) \times 0,5 \times \frac{39,9 \times 10^{9} \mathrm{rub}}{72700 \text { people }} \times 29,21\right.$ years $-\frac{4,6 \times 10^{9} \mathrm{rub}}{458452 \text { people }} \times(77,83$ years $-29,21$ years $\left.)\right]+$ $+\left[0,554 \times 0,5 \times \frac{39,9 \times 10^{9} \mathrm{rub}}{72700 \text { people }} \times 26,47\right.$ years $-\frac{4,6 \times 10^{9} \mathrm{rub}}{458545 \text { pepple }} \times(84,18$ years $-26,47$ years $\left.)\right]=$ $=0,006532 \times 10^{9}$ rub.per $\cdot$ one $\cdot$ persone

\section{Summary}

The socio-demographic losses inflicted by the death of infants in the Republic of Ingushetia consist in a reduction of:

- The life expectancy of a newborn (by 1.21-1.42 years for males and by $0.76-1.48$ years for females); 